\title{
The effect of temperature shifts on protein synthesis by the psychrophilic bacterium Vibrio sp. strain ANT-300
}

\author{
TADASHI ARAKI \\ The Institute of Low Temperature Science, Hokkaido University, Sapporo 060, Japan
}

(Received 20 August 1990; revised 3 December 1990; accepted 17 December 1990)

\begin{abstract}
In the psychrophilic bacterium Vibrio sp. strain ANT-300, the temperature-related characteristics of protein synthesis in cells grown at $0^{\circ} \mathrm{C}$ differed from those of cells grown at $13{ }^{\circ} \mathrm{C}$. Cells grown at $0{ }^{\circ} \mathrm{C}$ and $13{ }^{\circ} \mathrm{C}$ transported amino acids at the same rates, dependent on the temperature at which rates were measured. The rates of protein synthesis in extracts of cells grown at $0{ }^{\circ} \mathrm{C}$ and at $13{ }^{\circ} \mathrm{C}$ differed, as a result of the changes in the properties of the soluble fraction involved in protein synthesis. Concurrently, levels of more than 24 polypeptides in the soluble fraction changed considerably. These results suggest that the difference in temperature dependence of protein synthesis in cells grown at various temperatures may be brought about by specific changes in the levels of a small number of polypeptides (less than $15 \%$ of the total number of proteins detected by silver-staining) in response to a change in temperature.
\end{abstract}

\section{Introduction}

It is well known that the relationships between temperature and the growth rate of bacteria are characterized by straight lines in the Arrhenius profiles in the middle temperature range, with distinct changes in slope at temperatures higher and lower than the optimum range. The forms of such Arrhenius curves are quite similar among various species and strains of bacteria that possess the capacity to grow at a range of different temperatures (Mohr \& Krawiec, 1980). There are no significant correlations between the values of temperature characteristics representing the Arrhenius constant $\left(\mu_{\mathrm{A}}\right)$ of the exponential growth rates in the cells of psychrophiles, psychrotrophs and mesophiles (Ratkowsky et al., 1982, 1983; Reichardt \& Morita, 1982).

Given the myriad of chemical reactions involved in growth, it would seem likely that the relationship between temperature and metabolic control must be quite complex. It is unclear how cells regulate their metabolic reactions so as to maximize their growth rates in the middle temperature range, over which their temperature characteristics remain approximately constant. It is also unclear how such optimization is prevented at temperatures outside this range. Several previous studies have found that one or more reactions become rate-limiting at extreme temperatures, either

Abbreviation: AIB, $\alpha$-aminoisobutyric acid high (Patterson \& Gillespie, 1972) or low (Broeze et al., 1978; Das \& Goldstein, 1968; Inniss \& Ingraham, 1978), as a result of the inability of cells to compensate for thermally induced changes in the conformation of proteins.

With the advent of methods for measuring the amounts of individual proteins, it has been shown that metabolic coordination in Escherichia coli within the middle temperature range seems to be controlled predominantly by modulation of enzymic activities rather than by modulation of the levels of individual proteins, and that restricted growth outside this range is accompanied by marked changes in the levels of a relatively small number of proteins (Herendeen et al., 1979; Lemaux et al., 1978). After a shift-up in temperature, transient changes in the rates of synthesis of a small number of proteins appear to be induced by the promotion of transcription that is regulated by an alternative sigma subunit of RNA polymerase $\left(\sigma^{32}\right)$, the product of the rpoH ( $h t p R$ ) gene, a process that is known as the heat-shock response (Cowing et al., 1985; Grossman et al., 1984; Neidhardt \& VanBogelen, 1981; Taylor et al., 1984; Yamamori et al., 1978; Yamamori \& Yura, 1980, 1982; Yura et al., 1984). Furthermore, more than a dozen proteins, none of which are heat-shock proteins, have been shown to be induced by a shift-down in temperature (Goldstein et al., 1990; Jones et al., 1987).

It has been also shown that, in psychrotrophic and psychrophilic bacteria, a shift-up in temperature induces 
increases in the rates of synthesis of heat-shock proteins (McCallum et al., 1986). However, there are no studies, to our knowledge, of the effects of temperature on the levels of individual proteins in psychrotrophic and psychrophilic bacteria. In order to clarify the way in which psychrophilic bacteria regulate their metabolism so that they can grow efficiently at extremely low temperatures, the effects of temperature on the rates of protein synthesis in vivo and in vitro, and also on the levels of individual proteins in Vibrio sp. strain ANT-300 cells, were examined. The results reported here indicate that a temperature characteristic representing the activation energy of protein synthesis in vivo and in vitro in cells grown at $0{ }^{\circ} \mathrm{C}$ differed from those of cells grown at $13{ }^{\circ} \mathrm{C}$, and that the levels of more than 24 polypeptides in the soluble fraction changed considerably, depending on the growth temperature.

\section{Methods}

Bacterial strain and medium. Vibrio sp. strain ANT-300 was obtained from Dr R. Y. Morita (Oregon State University, USA). Cells were grown in a complex medium $(\mathrm{pH} 7.8)$ that contained $1.2 \mathrm{~g}$ yeast extract, $2.3 \mathrm{~g}$ trypticase peptone, $0.3 \mathrm{~g}$ sodium citrate, $0.3 \mathrm{~g}$ potassium glutamate, $50 \mathrm{mg} \mathrm{NaNO}_{3}$ and $5 \mathrm{mg} \mathrm{FeSO}_{4}$ per litre of artificial seawater, the latter consisting of $2.8 \%(\mathrm{w} / \mathrm{v})$ Jamarine-S in distilled water, as described by Geesey \& Morita (1975).

Preparation of cell-free extracts. Cells were grown to the lateexponential phase at either $0^{\circ} \mathrm{C}$ or $13{ }^{\circ} \mathrm{C}$, harvested by centrifugation at $10000 \mathrm{~g}$ for $10 \mathrm{~min}$ at $0^{\circ} \mathrm{C}$ and washed with artificial seawater supplemented with $50 \mathrm{mM} \mathrm{KCl}, 10 \mathrm{~mm}$-magnesium acetate, $1 \mathrm{~mm}$ dithiothreitol, $10 \mathrm{~mm}$-Tris/ $\mathrm{HCl}(\mathrm{pH} 7 \cdot 6)$. Cells were ruptured with a French press (Ohtake, Japan), and crude S30 extracts were prepared by the method of Nirenberg (1963). These extracts were fractionated into a supernatant ( $\mathrm{S} 100$ fraction) and a pellet by centrifugation at $105000 \mathrm{~g}$ for $120 \mathrm{~min}$. The pellets were resuspended in the initial volume of the supplemented seawater by gentle homogenization and centrifuged again at $105000 \mathrm{~g}$ for $120 \mathrm{~min}$. After the removal of the supernatants, washed pellets ( 100 fraction) were resuspended in the initial volume of the supplemented seawater.

Assays of protein synthesis in vivo and in vitro. Cells were grown to the mid-exponential phase of growth at either $0^{\circ} \mathrm{C}$ or $13{ }^{\circ} \mathrm{C}$. Portions of each culture $(5 \mathrm{ml})$ were mixed with 2 vols of medium, pre-equilibrated to the desired temperature, and held at this temperature. $\left[{ }^{14} \mathrm{C}\right]$ Leucine $\left(12.9 \mathrm{GBq} \mathrm{mmol}^{-1}\right)$ was added to a final concentration of $74 \mathrm{KBq} \mathrm{ml}^{-1}$, and $0.5 \mathrm{ml}$ portions of culture were removed at appropriate intervals and mixed with $5 \mathrm{ml}$ cold $10 \%(\mathrm{w} / \mathrm{v})$ trichloroacetic acid (TCA). The precipitated samples were filtered through membrane filters $(0.45 \mu \mathrm{m}$; Toyo Roshi Kaisha, Japan) and washed with $10 \mathrm{ml}$ cold $10 \%$ TCA; and then the filters were put into scintillation vials which contained $0.3 \mathrm{ml}$ ethyleneglycol monoethylether. Aquasol- $2(5 \mathrm{ml})$ was added to each vial, and the radioactivity was counted in an LKB RackBeta liquid scintillation counter.

For protein synthesis in vitro, the reaction mixture consisted of $60 \mathrm{~mm}-\mathrm{NH}_{4} \mathrm{Cl}, 20 \mathrm{~mm}-\mathrm{KCl}, 8 \mathrm{~mm}$-magnesium acetate, $1 \mathrm{~mm}-\mathrm{ATP}$, $20 \mu \mathrm{M}$-GTP, $5 \mathrm{~mm}$-potassium phosphoenolpyruvate, $30 \mu \mathrm{g}$ of pyruvate kinase $\mathrm{ml}^{-1}, 50 \mathrm{mM}-\mathrm{Tris} / \mathrm{HCl}(\mathrm{pH} 7.6)$ and $74 \mathrm{KBq} \mathrm{ml}^{-1}$ of a mixture of
${ }^{14} \mathrm{C}$-labelled amino acids. To initiate the reaction, $\mathrm{S} 30$ extracts $(0.5 \mathrm{ml}$; about $30 \mathrm{mg}$ protein $\mathrm{ml}^{-1}$ ) were added to the above reaction mixture $(1.0 \mathrm{ml})$, which was pre-equilibrated to the appropriate test temperature. At regular intervals, aliquots $(0 \cdot 2 \mathrm{ml})$ were removed and put into tubes containing $2 \mathrm{ml}$ cold $10 \% \mathrm{TCA}$; then samples were treated for counting of radioactivity as described above.

The rates of protein synthesis in vivo and in vitro were calculated from the amounts of amino acids incorporated into the TCA-insoluble fraction during the course of incubations for $60 \mathrm{~min}$ and $10 \mathrm{~min}$, respectively.

Transport of amino acids into whole cells. Cells grown to an optical density of about 0.2 units at $600 \mathrm{~nm}$ at either $0{ }^{\circ} \mathrm{C}$ or $13{ }^{\circ} \mathrm{C}$ were harvested and resuspended to give $1 / 50$ of the original culture volume in the artificial seawater $(\mathrm{pH} 7.8)$. Portions of the suspension $(1.0 \mathrm{ml})$ were mixed with $4.0 \mathrm{ml}$ of artificial seawater pre-equilibrated to the desired temperature, and then either $\left[{ }^{14} \mathrm{C}\right]$ leucine $\left(12.9 \mathrm{GBq} \mathrm{mmol}^{-1}\right)$ or $\alpha$ aminoiso $\left[{ }^{14} \mathrm{C}\right]$ butyrate $\left(2.26 \mathrm{GBq} \mathrm{mmol}^{-1}\right)$ was added to a final concentration of $18.5 \mathrm{KBq} \mathrm{ml}^{-1}$. At appropriate intervals, aliquots $(0.2 \mathrm{ml})$ were passed over prewashed membrane filters which were then washed three times with $2 \mathrm{ml}$ of artificial seawater. After washing, filters were put into scintillation vials and treated for counting of radioactivity as described above. Other samples were immersed in $5 \mathrm{ml}$ portions of cold $10 \%$ TCA and then separated into TCA-soluble and TCA-insoluble fractions by centrifugation at $3000 \mathrm{~g}$ for $10 \mathrm{~min}$. The TCA-insoluble fraction was resuspended in the artificial seawater and passed over prewashed membrane filters which were then washed three times with $5 \mathrm{ml}$ cold $10 \%$ TCA. These fractions were treated for counting of radioactivity as described above.

Analysis of proteins by two-dimensional gel electrophoresis. Cells grown to the mid-exponential phase at $0{ }^{\circ} \mathrm{C}$ were immediately labelled with $\left[{ }^{14} \mathrm{C}\right]$ leucine $\left(12.9 \mathrm{GBq} \mathrm{mmol}^{-1}, 74 \mathrm{KBq} \mathrm{ml}^{-1}\right)$ for $60 \mathrm{~min}$ at $0{ }^{\circ} \mathrm{C}$ or for $30 \mathrm{~min}$ at $13^{\circ} \mathrm{C}$. Other portions were transferred to a temperature of $13^{\circ} \mathrm{C}$ and aliquots of culture were removed after a further 3,6 and $30 \mathrm{~h}$ and then labelled for $30 \mathrm{~min}$ at $13^{\circ} \mathrm{C}$. Cells labelled with $\left[{ }^{1+} \mathrm{C}\right]$ leucine were collected by centrifugation, washed with the artificial seawater and then resuspended in $10 \mathrm{~mm}$-Tris/ $\mathrm{HCl}$ buffer $(\mathrm{pH} 7.4)$ that contained $5 \mathrm{mM}-\mathrm{MgCl}_{2}, 10 \mathrm{mM}-\mathrm{PMSF}$, and $50 \mu \mathrm{g}$ pancreatic RNAase $\mathrm{ml}^{-1}$. The cells were lysed by sonication and then lysates were treated with $50 \mu \mathrm{g}$ DNAase $\mathrm{ml}^{-1}$ at $0{ }^{\circ} \mathrm{C}$ for $15 \mathrm{~min}$. Solid urea was added to a final concentration of $9 \mathrm{M}$-urea. After the urea had dissolved completely at room temperature, an equal volume of lysis buffer, which contained $9 \mathrm{M}-$ urea, $2 \%(\mathrm{v} / \mathrm{v})$ Nonidet P-40, $1.6 \%$ (v/v) Ampholine (pH 5-7), $0.4 \%$ Ampholine ( $\mathrm{pH} \mathrm{3-10)}$ and 5\% (v/v) mercaptoethanol, was added.

Two-dimensional gel electrophoresis was done by the method of O'Farrell (1975). Slab gels were stained with 'Daiichi', silver stain, impregnated with Enlightning as an enhancer and dried for autoradiography. Fluorographs were obtained by exposing Fuji X-ray films to the treated slab gels.

Nomenclature for polypeptides. Cellular proteins were separated by isoelectric focusing in one dimension ('horizontal') and by electrophoresis in the presence of SDS in the second dimension ('vertical'). The individual polypeptides that were detected by silver staining were numbered from the upper left-hand corner of the gel horizontally to the right-hand corner. The numbering of polypeptides was continued from the upper line of polypeptides to the lowest line in the same manner, ending in the bottom right-hand corner.

Chemicals. Yeast extract and Trypticase peptone were obtained from Difco and BBL, respectively. Jamarine-S was purchased from Jamarine Laboratories. (Osaka, Japan). L- $\left[\mathrm{U}-{ }^{14} \mathrm{C}\right]$ Leucine, $\alpha$-amino$\left[1^{-14} \mathrm{C}\right.$ lisobutyric acid and the $\mathrm{U}^{-14} \mathrm{C}$ labelled amino acid mixture were obtained from Amersham. Aquasol-2 and Enlightning were obtained from New England Nuclear. Ampholines were obtained from LKB 


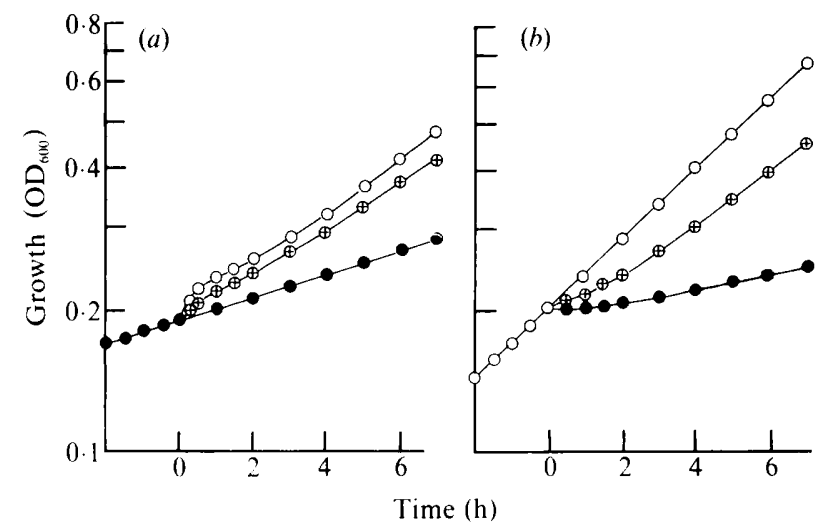

Fig. 1. Effects of temperature on growth of cells of Vibrio sp. strain ANT-300. A culture incubated at either $0{ }^{\circ} \mathrm{C}(a)$ or $13{ }^{\circ} \mathrm{C}(b)$ was divided into three parts and the various portions were incubated at $13^{\circ} \mathrm{C}(\mathrm{O}), 7^{\circ} \mathrm{C}(\oplus)$ or $0^{\circ} \mathrm{C}(\bullet)$ from time zero.

Nonidet P-40 was purchased from BHL Chemicals. Acrylamide, methylene-bisacrylamide and tetramethylene diamine were purchased from Eastman-Kodak. 'Daiichi' silver stain was purchased from Daiichi Pure Chemicals. (Tokyo, Japan). Pancreatic RNAase, DNAase and PMSF were purchased from Sigma.

\section{Results}

\section{Growth and protein synthesis after a shift in temperature}

A shift-up in temperature from $0{ }^{\circ} \mathrm{C}$ to either $7{ }^{\circ} \mathrm{C}$ or $13^{\circ} \mathrm{C}$ resulted in an increased rate of growth of Vibrio sp. strain ANT-300, as measured by the optical density of cultures at $600 \mathrm{~nm}$ (Fig. 1). An initial stimulation of growth was followed by a period of several hours during which the rates gradually increased until a final steadystate growth rate, characteristic of the new growth temperature, was established. The final phase is not shown in Fig. 1(a), but the steady-state growth rate at $13{ }^{\circ} \mathrm{C}$ (doubling time $5.5 \mathrm{~h}$ ) was the same as that of cells grown at $13^{\circ} \mathrm{C}$ (Fig. $1 b$ ). After a shift-down in temperature from $13{ }^{\circ} \mathrm{C}$ to $0{ }^{\circ} \mathrm{C}$ or $7{ }^{\circ} \mathrm{C}$, the growth rate of cells was immediately reduced. After this, there was a very slow and gradual increase in growth rate. An eventual steady-state rate, characteristic of incubation at $0{ }^{\circ} \mathrm{C}$ (doubling time $11 \mathrm{~h}$ ) was established almost $33 \mathrm{~h}$ after the shift-down to $0^{\circ} \mathrm{C}$.

The effects of temperature on protein synthesis by cells grown at $0{ }^{\circ} \mathrm{C}$ and $13^{\circ} \mathrm{C}$ are shown in Fig. 2. The rates of protein synthesis increased with the increase in temperature, but showed a different temperature dependence. In cells grown at $0{ }^{\circ} \mathrm{C}$, protein synthesis at $7{ }^{\circ} \mathrm{C}$ and $13{ }^{\circ} \mathrm{C}$ continued at a rate equal to 1.7 and 2.3 times, respectively, that in cells incubated at $0{ }^{\circ} \mathrm{C}$. The rate of protein synthesis during incubation at $13^{\circ} \mathrm{C}$ of cells grown at $13{ }^{\circ} \mathrm{C}$ was approximately 1.3 times higher than

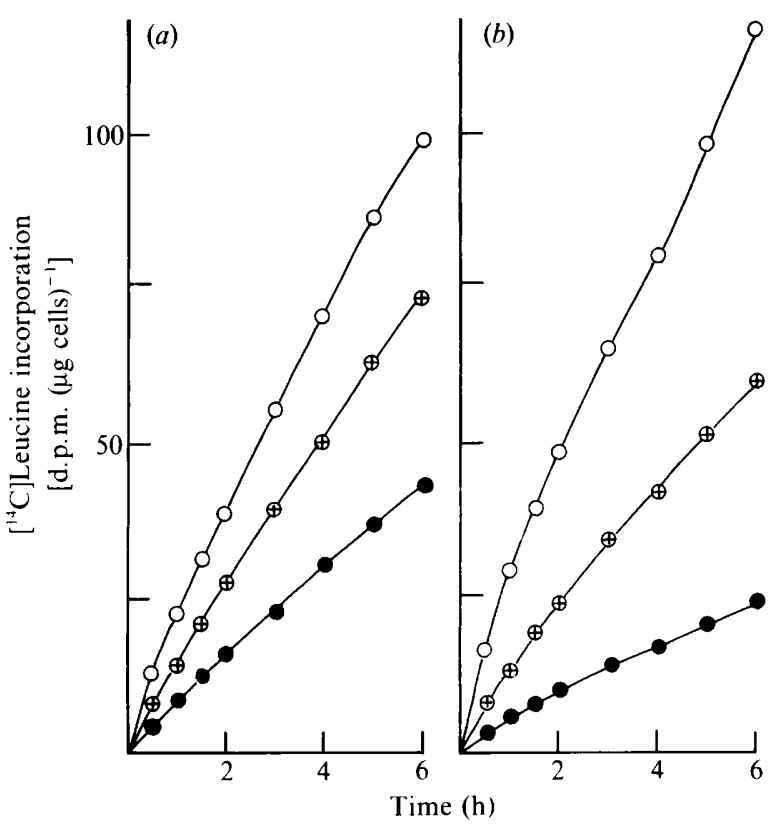

Fig. 2. Effects of temperature on rates of protein synthesis in cells of Vibrio sp. strain ANT-300 grown at $0{ }^{\circ} \mathrm{C}(a)$ and $13{ }^{\circ} \mathrm{C}(b)$. Results are means from three independent experiments. $O$, Incubation temperature $13^{\circ} \mathrm{C} ; \oplus, 7^{\circ} \mathrm{C} ; 0,0^{\circ} \mathrm{C}$.

that of cells grown at $0{ }^{\circ} \mathrm{C}$, but the rate of protein synthesis in cells grown at $13{ }^{\circ} \mathrm{C}$ was very significantly reduced by incubation at either $7^{\circ} \mathrm{C}$ or $0^{\circ} \mathrm{C}$. The rate of protein synthesis during incubation at $0{ }^{\circ} \mathrm{C}$ was reduced to approximately $20 \%$ of the value during incubation at $13{ }^{\circ} \mathrm{C}$, as compared to the $50 \%$ reduction in the case of cells grown at $0{ }^{\circ} \mathrm{C}$.

\section{Temperature dependence of amino acid transport}

To investigate whether the discrepancy in temperaturedependent protein synthesis resulted from a restricted response of substrate transport to various temperatures, the effects of temperature on the accumulation of amino acids in cells grown at $0{ }^{\circ} \mathrm{C}$ and in cells grown at $13{ }^{\circ} \mathrm{C}$ were examined. Table 1 compares the temperaturedependent uptake of $\alpha$-aminoisobutyrate (AIB) by cells grown at $0{ }^{\circ} \mathrm{C}$ and by cells grown at $13{ }^{\circ} \mathrm{C}$. Both groups of cells accumulated $\left[{ }^{14} \mathrm{C}\right] \mathrm{AIB}$ at a constant rate for at least $5 \mathrm{~min}$, after which the rates of accumulation decreased gradually. The rate of accumulation of AIB increased with increasing temperature of incubation. The ratios of the initial rates of accumulation at $7{ }^{\circ} \mathrm{C}$ and $13{ }^{\circ} \mathrm{C}$ to that at $0{ }^{\circ} \mathrm{C}$ were $2 \cdot 19$ and $5 \cdot 22$, respectively, for cells grown at $0^{\circ} \mathrm{C}$, and $2 \cdot 24$ and $5 \cdot 28$, respectively, for cells grown at $13^{\circ} \mathrm{C}$. The relative response to higher temperatures was the same in both groups of cells. All of the radioactive materials accumulated in whole cells could be extracted 
Table 1. Temperature dependence of $\left[{ }^{14} \mathrm{C}\right] \mathrm{AIB}$ transport by cells grown at $0^{\circ} \mathrm{C}$ and $13^{\circ} \mathrm{C}$

The initial rates were estimated from tangents drawn to uptake curves at zero time. Results in this Table are means of values from three independent experiments.

\begin{tabular}{|c|c|c|c|c|c|c|c|}
\hline \multirow[b]{2}{*}{ Sample } & \multirow[b]{2}{*}{ Temp. $\left({ }^{\circ} \mathrm{C}\right)$} & \multicolumn{5}{|c|}{$\begin{array}{c}10^{-3} \times\left[{ }^{14} \mathrm{C}\right] \text { AIB accumulation } \\
{\left[\text { d.p.m. }(\mathrm{mg} \text { cells })^{-1}\right]}\end{array}$} & \multirow{2}{*}{$\begin{array}{c}\text { Ratio } \\
\text { of } \\
\text { initial rates }\end{array}$} \\
\hline & & $2 \mathrm{~min}$ & $5 \mathrm{~min}$ & $10 \mathrm{~min}$ & $15 \mathrm{~min}$ & $30 \mathrm{~min}$ & \\
\hline $\begin{array}{l}\text { Cells grown } \\
\text { at } 0^{\circ} \mathrm{C}\end{array}$ & $\begin{array}{r}0 \\
7 \\
13\end{array}$ & $\begin{array}{l}1 \cdot 1 \\
2 \cdot 4 \\
5 \cdot 6\end{array}$ & $\begin{array}{r}2 \cdot 7 \\
5.9 \\
14 \cdot 1\end{array}$ & $\begin{array}{r}5 \cdot 2 \\
12 \cdot 1 \\
27 \cdot 3\end{array}$ & $\begin{array}{r}7 \cdot 3 \\
17.5 \\
32 \cdot 7\end{array}$ & $\begin{array}{l}13 \cdot 2 \\
31 \cdot 9 \\
42 \cdot 0\end{array}$ & $\begin{array}{l}1 \cdot 00 \\
2 \cdot 19 \\
5 \cdot 22\end{array}$ \\
\hline $\begin{array}{l}\text { Cells grown } \\
\text { at } 13^{\circ} \mathrm{C}\end{array}$ & $\begin{array}{r}0 \\
7 \\
13\end{array}$ & $\begin{array}{l}1 \cdot 0 \\
2 \cdot 2 \\
5 \cdot 3\end{array}$ & $\begin{array}{r}2 \cdot 5 \\
5 \cdot 6 \\
13 \cdot 2\end{array}$ & $\begin{array}{r}4 \cdot 3 \\
12 \cdot 2 \\
22 \cdot 7\end{array}$ & $\begin{array}{r}6 \cdot 4 \\
17 \cdot 5 \\
30 \cdot 6\end{array}$ & $\begin{array}{l}12 \cdot 5 \\
31 \cdot 1 \\
42 \cdot 5\end{array}$ & $\begin{array}{l}1 \cdot 00 \\
2 \cdot 24 \\
5 \cdot 28\end{array}$ \\
\hline
\end{tabular}

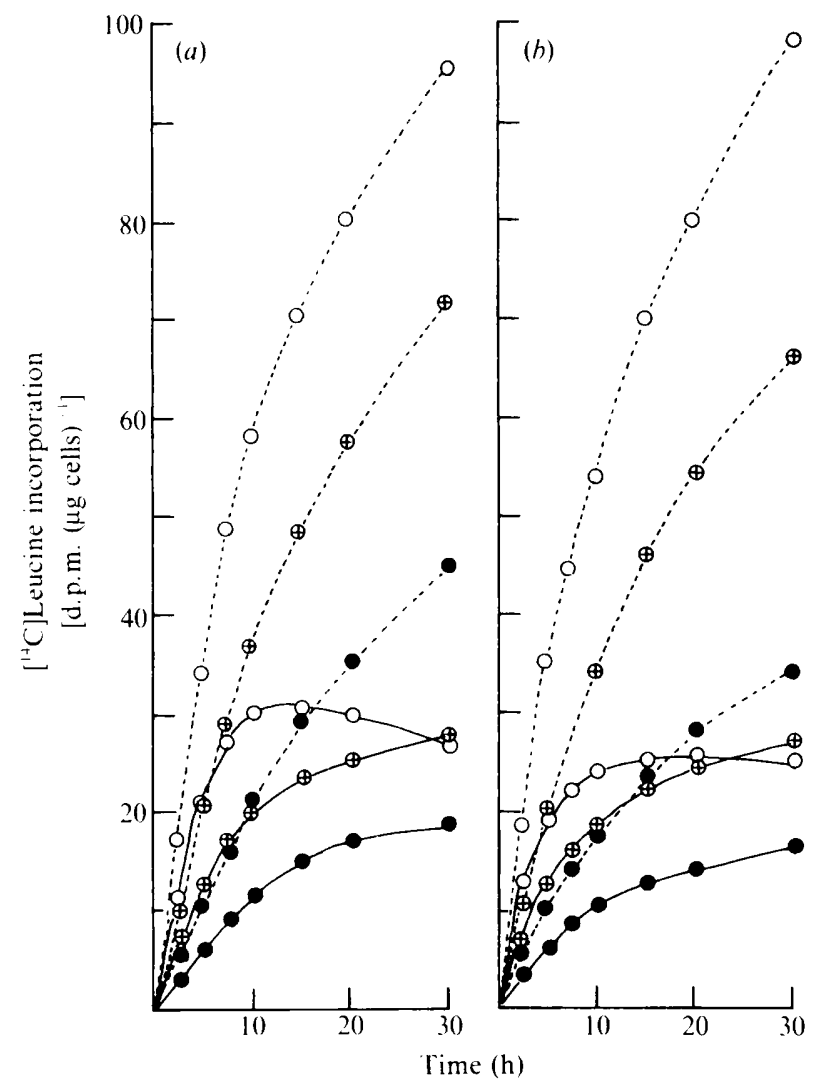

Fig. 3. Effects of temperature on incorporation of $\left[{ }^{14} \mathrm{C}\right]$ leucine. Cells grown at either $0{ }^{\circ} \mathrm{C}(a)$ or $13^{\circ} \mathrm{C}(b)$ were labelled with $\left[{ }^{14} \mathrm{C}\right]$ leucine at $13^{\circ} \mathrm{C}(\mathrm{O}), 7^{\circ} \mathrm{C}(\oplus)$ or $0^{\circ} \mathrm{C}(\Theta) \cdot\left[{ }^{14} \mathrm{C}\right]$ Leucine incorporation was measured in whole cells $(--)$ and in a TCA-soluble fraction $(--)$.

by treating the cells with either $10 \%$ TCA or water at $100{ }^{\circ} \mathrm{C}$ for $15 \mathrm{~min}$. The accumulated AIB had the same mobility during thin-layer chromatography as pure AIB. These results suggest that the accumulated AIB is free in the cytoplasm and is in an unchanged form. By contrast, leucine was accumulated first in the cytoplasm and then it was incorporated into cellular components, in particular into proteins. Fig. 3 shows the effects of temperature on the uptake of $\left[{ }^{1+} \mathrm{C}\right]$ leucine in the total-cell and TCAsoluble fractions from cells grown at $0^{\circ} \mathrm{C}$ and from cells grown at $13{ }^{\circ} \mathrm{C}$. The accumulation of ${ }^{1+} \mathrm{C}$-leucine in the two fractions from both groups of cells continued at a constant rate for at least $3 \mathrm{~min}$ and then lower rates were recorded. The initial rate of accumulation in the total-cell and TCA-soluble fractions of cells grown at $0{ }^{\circ} \mathrm{C}$ responded to different temperatures of incubation in a manner similar to that of cells grown at $13^{\circ} \mathrm{C}$. In the TCA-soluble fraction of both groups of cells, the level of accumulated leucine reached a maximum after $10 \mathrm{~min}$ at $13{ }^{\circ} \mathrm{C}$, and after about $30 \mathrm{~min}$ at $7{ }^{\circ} \mathrm{C}$ and $0^{\circ} \mathrm{C}$, and then decreased gradually. The accumulation of leucine in the total-cell fraction of both groups of cells showed a different response to incubation temperatures as time passed.

Effects of temperature on protein synthesis by cell-free extracts

The kinetics and extent of incorporation of ${ }^{14} \mathrm{C}$-labelled amino acids by crude $\mathrm{S} 30$ extracts prepared from cells grown at $0{ }^{\circ} \mathrm{C}$ and cells grown at $13^{\circ} \mathrm{C}$ are shown in Fig. 4. The activities of $\mathrm{S} 30$ extracts from cells grown at $13{ }^{\circ} \mathrm{C}$ were usually 3 to 5 times higher than those of cells grown at $0{ }^{\circ} \mathrm{C}$, although the activities varied from preparation to preparation. At $0{ }^{\circ} \mathrm{C}, \mathrm{S} 30$ extracts from cells grown at $13{ }^{\circ} \mathrm{C}$ incorporated amino acids into the TCA-insoluble fraction at approximately 29 to $33 \%$ of the rate at $13{ }^{\circ} \mathrm{C}$, whereas $\mathrm{S} 30$ extracts from cells grown at $0{ }^{\circ} \mathrm{C}$ synthesized proteins at $0{ }^{\circ} \mathrm{C}$ at approximately 45 to $50 \%$ of the rate at $13{ }^{\circ} \mathrm{C}$. The effects of temperature on the rates of protein synthesis by whole cells grown at $0^{\circ} \mathrm{C}$ and at $13^{\circ} \mathrm{C}$ and the rates of protein synthesis in vitro by $\mathrm{S} 30$ 


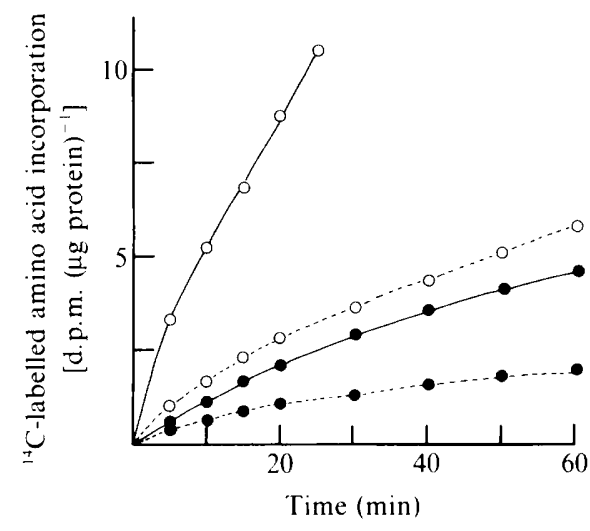

Fig. 4. Effects of temperature on protein synthesis in vitro. Crude S30 extracts were prepared from cells grown at either $13{ }^{\circ} \mathrm{C}(\mathrm{O})$ or $0{ }^{\circ} \mathrm{C}$ (O); the extracts were then incubated with a mixture of ${ }^{14} \mathrm{C}$-labelled amino acids at $13{ }^{\circ} \mathrm{C}\left(-\right.$ ) or $0{ }^{\circ} \mathrm{C} \mathrm{(---)}$. Data obtained from a single preparation are plotted. Although there was an approximately $30 \%$ difference in the absolute values obtained from various preparations, the same temperature dependence was observed in all experiments.

extracts from both groups of cells were compared (Fig. 5). The patterns of temperature dependence of the rates of protein synthesis in vivo and in vitro observed with cells grown at $0{ }^{\circ} \mathrm{C}$ were different from those observed with cells grown at $13^{\circ} \mathrm{C}$, and there was a somewhat higher relative decrease in the rate of protein synthesis in whole cells grown at $13{ }^{\circ} \mathrm{C}$.

The fractions designated $\mathrm{S} 100$ and R100 were prepared separately from crude $\mathrm{S} 30$ extracts of cells grown at $0^{\circ} \mathrm{C}$ and at $13^{\circ} \mathrm{C}$. They were then combined, and the

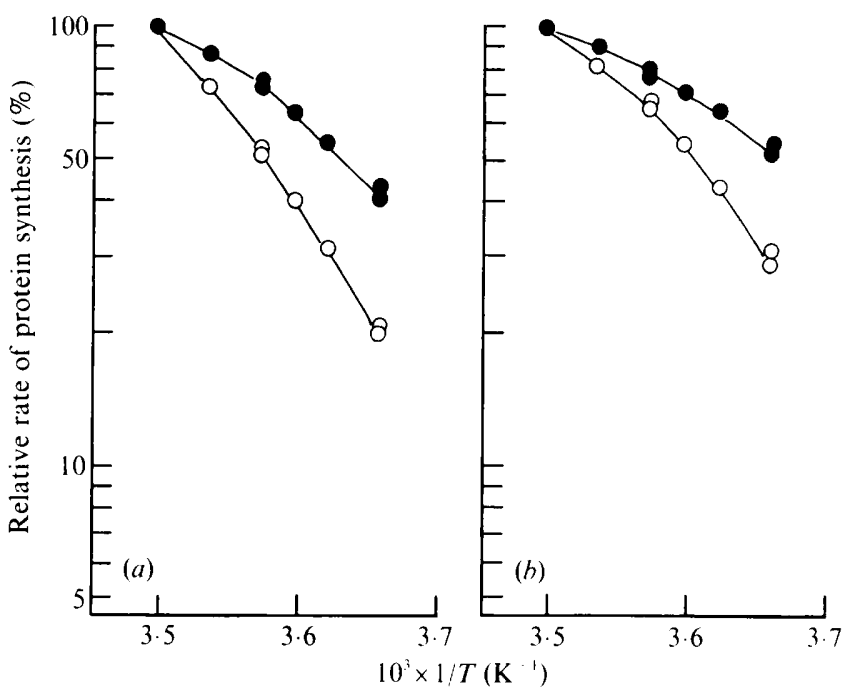

Fig. 5. Temperature dependence of protein synthesis in vivo and in vitro. Cells were grown at $13{ }^{\circ} \mathrm{C}(\mathrm{O})$ and at $0{ }^{\circ} \mathrm{C}(\bigcirc)$. The rates of protein synthesis in whole cells $(a)$ and in $\mathrm{S} 30$ extracts $(b)$ at the temperatures indicated are shown.

capacities of the combined fractions to synthesize proteins at $0{ }^{\circ} \mathrm{C}$ and $13{ }^{\circ} \mathrm{C}$ were determined (Table 2). Compared with the activity of S30 extracts from cells grown at $13{ }^{\circ} \mathrm{C}$, the activities of a mixture of the S100 fraction from cells grown at $13{ }^{\circ} \mathrm{C}$ with washed ribosomes from cells grown at either $13{ }^{\circ} \mathrm{C}$ or $0{ }^{\circ} \mathrm{C}$ decreased by approximately $20 \%$ and $40 \%$ respectively, but the ratios of activities at $0{ }^{\circ} \mathrm{C}$ to those at $13{ }^{\circ} \mathrm{C}$ did not change. By contrast, in $\mathrm{S} 30$ extracts from cells grown at $0{ }^{\circ} \mathrm{C}$ the ratios of activities at $0{ }^{\circ} \mathrm{C}$ to those at $13{ }^{\circ} \mathrm{C}$

Table 2. Temperature-dependent protein synthesis in combinations of soluble fractions and ribosomes prepared from cells grown at $0^{\circ} \mathrm{C}$ and

$$
13{ }^{\circ} \mathrm{C}
$$

Values in parentheses indicate the temperature at which cells were grown before preparation of the S30 and S100 fractions and the washed ribosomes (R100). Reaction mixtures were set up as described in Methods using $1.14 \mathrm{mg}$ protein of an $\mathrm{S} 30$ fraction $\mathrm{ml}^{-1}, 0.48 \mathrm{mg}$ protein of an $\mathrm{S} 100$ fraction $\mathrm{ml}^{-1}$ and $0.66 \mathrm{mg}$ protein of an $\mathrm{R} 100$ fraction $\mathrm{ml}^{-1}$, as indicated. Data represent radioactivity incorporated into the TCA-insoluble fraction over a period of $10 \mathrm{~min}$. Results in this Table are means of values from three independent experiments.

\begin{tabular}{llcc}
\hline \hline & $\begin{array}{c}10^{-3} \times{ }^{14} \mathrm{C} \text {-labelled amino } \\
\text { acid incorporation } \\
\left.\text { (d.p.m. ml })^{-1}\right)\end{array}$ & \\
\cline { 2 - 4 } Fractions present & $0^{\circ} \mathrm{C}$ & $13^{\circ} \mathrm{C}$ & $\begin{array}{c}\text { Ratio of activities } \\
\text { at } 0^{\circ} \mathrm{C} \text { and } 13^{\circ} \mathrm{C}\end{array}$ \\
\hline S30 $\left(13^{\circ} \mathrm{C}\right)$ & 1.53 & 5.21 & 0.294 \\
S100 $\left(13{ }^{\circ} \mathrm{C}\right)+\mathrm{R} 100\left(13^{\circ} \mathrm{C}\right)$ & 1.24 & 4.34 & 0.286 \\
S100 $\left(13^{\circ} \mathrm{C}\right)+\mathrm{R} 100\left(0^{\circ} \mathrm{C}\right)$ & 0.86 & 3.15 & 0.273 \\
S30 $\left(0^{\circ} \mathrm{C}\right)$ & 0.55 & 1.14 & 0.482 \\
S100 $\left(0^{\circ} \mathrm{C}\right)+\mathrm{R} 100\left(13^{\circ} \mathrm{C}\right)$ & 0.78 & 1.57 & 0.497 \\
S100 $\left(0^{\circ} \mathrm{C}\right)+\mathrm{R} 100\left(0^{\circ} \mathrm{C}\right)$ & 0.45 & 0.89 & 0.506 \\
\hline \hline
\end{tabular}



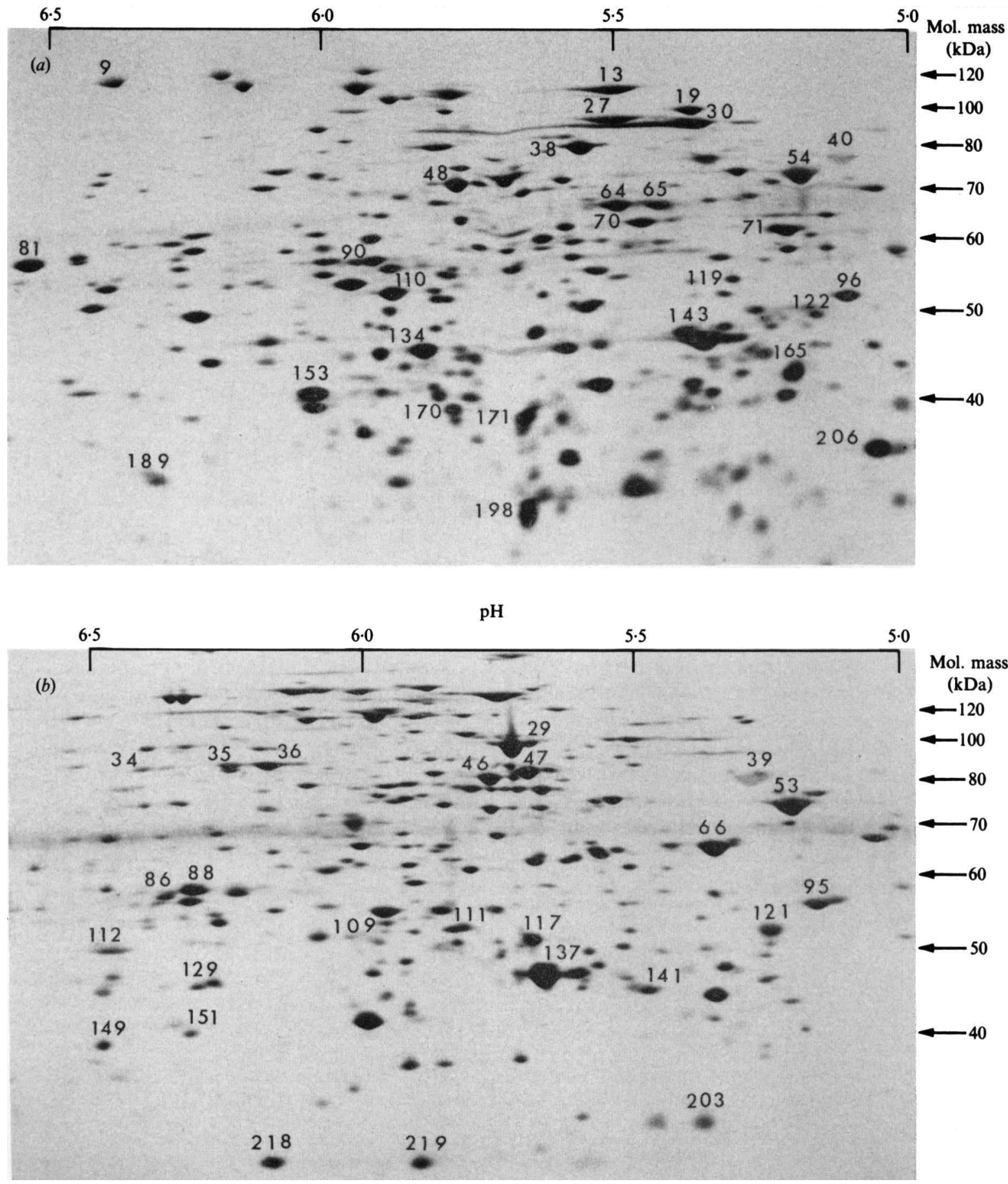

Fig. 6. Proteins in $\mathrm{S} 100$ fractions after fractionation by two-dimensional gel electrophoresis. An $\mathrm{S} 100$ fraction was prepared from cells grown at $0^{\circ} \mathrm{C}(a)$ and $13^{\circ} \mathrm{C}(b)$. The gels were stained with silver, and characteristic polypeptides in each sample numbered as described in Methods.

Fig. 7 (facing page). Effects of a shift-up in temperature on protein synthesis in cells of Vibrio sp. strain ANT-300 grown at $0{ }^{\circ} \mathrm{C}$. Cells were labelled with $\left[{ }^{14} \mathrm{C}\right]$ leucine for $60 \mathrm{~min}$ at $0^{\circ} \mathrm{C}(a)$ or for $30 \mathrm{~min}$ at $13{ }^{\circ} \mathrm{C}$ after $0 \mathrm{~h}(b), 3 \mathrm{~h}(c), 6 \mathrm{~h}(d)$, and $30 \mathrm{~h}(e)$ post-shift. The polypeptides characteristic of cells grown at $0^{\circ} \mathrm{C}$ and $13{ }^{\circ} \mathrm{C}$ are indicated by circles and boxes, respectively. In panels $(b)-(e)$, the numbers indicate polypeptides whose rates of synthesis were stimulated by a shift-up in temperature. 

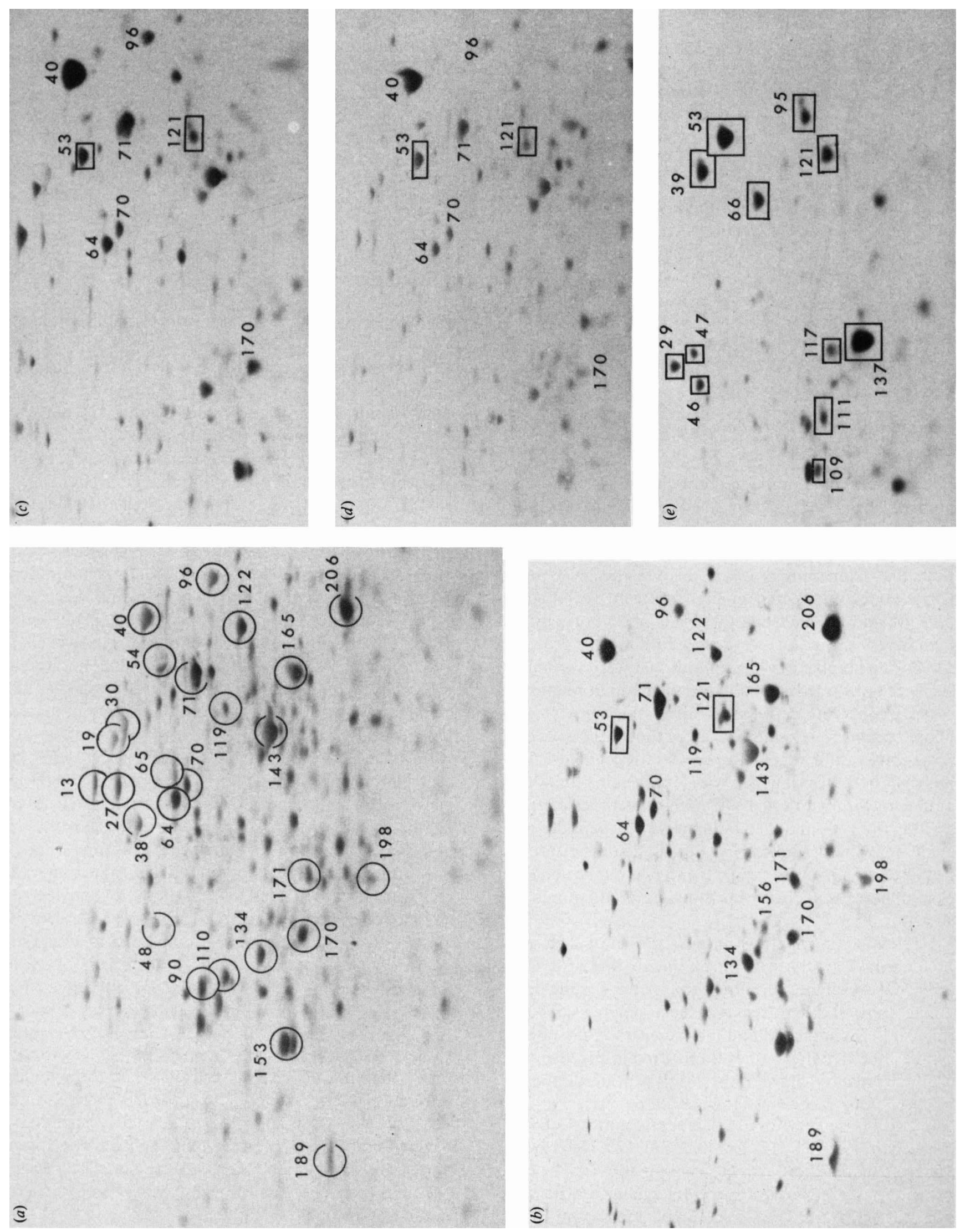
differed from that of $\mathrm{S} 30$ extracts from cells grown at $13{ }^{\circ} \mathrm{C}$. The ratio of activities at $0^{\circ} \mathrm{C}$ to those at $13^{\circ} \mathrm{C}$ of a mixture of the $\mathrm{S} 100$ fraction from cells grown at $0{ }^{\circ} \mathrm{C}$ with washed ribosomes from cells grown at either $0^{\circ} \mathrm{C}$ or $13{ }^{\circ} \mathrm{C}$ was almost the same as that of $\mathrm{S} 30$ extracts from cells grown at $0{ }^{\circ} \mathrm{C}$. In both cases, the ratios of activities at $0{ }^{\circ} \mathrm{C}$ to those at $13{ }^{\circ} \mathrm{C}$ were largely dependent on the characteristics of the $\mathrm{S} 100$ fractions, and not on the source of the washed ribosomal fractions. The activities in a mixture of the $\mathrm{S} 100$ fraction and washed ribosomes from cells grown at $0{ }^{\circ} \mathrm{C}$ decreased to approximately $80 \%$ of the pre-fractionation values at $0^{\circ} \mathrm{C}$ and $13{ }^{\circ} \mathrm{C}$. By contrast, the activities in a mixture in which the $\mathrm{S} 100$ fraction from cells grown at $0{ }^{\circ} \mathrm{C}$ was combined with washed ribosomes from cells grown at $13{ }^{\circ} \mathrm{C}$ were $40 \%$ greater than the activities of S30 extracts from cells grown at $0{ }^{\circ} \mathrm{C}$.

\section{Analysis of proteins by two-dimensional gel electrophoresis}

The electrophoretograms of proteins in $\mathrm{S} 100$ fractions prepared from cells grown at either $0{ }^{\circ} \mathrm{C}$ or $13{ }^{\circ} \mathrm{C}$ are shown in Fig. 6. The pattern of the polypeptides from the $\mathrm{S} 100$ fraction of cells grown at $0{ }^{\circ} \mathrm{C}$ differed qualitatively from that from cells grown at $13{ }^{\circ} \mathrm{C}$. The levels of 28 polypeptides (numbered in Fig. $6 a$ ) were very high in cells grown at $0{ }^{\circ} \mathrm{C}$, while the levels of 25 polypeptides (numbered in Fig. 6b) were very high in cells grown at $13{ }^{\circ} \mathrm{C}$. The number of polypeptides that were variable in terms of level was less than $15 \%$ of the total number of polypeptides (256) detected by silver-staining of electrophoretograms. To examine whether the synthesis of each polypeptide differed in temperature dependence, cells grown at $0{ }^{\circ} \mathrm{C}$ were labelled with $\left[{ }^{14} \mathrm{C}\right]$ leucine for $60 \mathrm{~min}$ at $0{ }^{\circ} \mathrm{C}$ or for $30 \mathrm{~min}$ at $13{ }^{\circ} \mathrm{C}$ at various times after the shift-up to $13^{\circ} \mathrm{C}$, and then radioactive polypeptides were analysed by autoradiography. Equal amounts of protein from each sample were subjected to two-dimensional gel electrophoresis and the resulting autoradiograms are shown in Fig. 7.

The major polypeptides in cells grown at $0{ }^{\circ} \mathrm{C}$ were preferentially synthesized during incubation at $0^{\circ} \mathrm{C}$, as indicated by circles in Fig. 7(a). After a shift-up in temperature the synthesis of most polypeptides was immediately stimulated and the increases in the rates of synthesis of 18 polypeptides (numbered in Fig. $7 \mathrm{~b}$ ) were especially marked. Two of these polypeptides, indicated by boxes (nos 53 and 121), were characteristic of cells grown at $13{ }^{\circ} \mathrm{C}$. The other 16 polypeptides (nos $40,64,70$, $71,96,119,122,134,143,156,165,170,171,189,198$ and 206) were characteristic of cells grown at $0^{\circ} \mathrm{C}$. The rates of synthesis of these polypeptides changed with time after the shift-up to $13^{\circ} \mathrm{C}$. Of 16 polypeptides, the rates of synthesis of eight (nos 119, 134, 143, 156, 165, 189, 198 and 206) were reduced after $3 \mathrm{~h}$ post-shift (Fig. $7 \mathrm{c}$ ), while the remaining eight polypeptides (nos 40, 53, 64, 70, 71, 96,121 and 170) continued to be synthesized until $6 \mathrm{~h}$ post-shift (Fig. 7d). After $30 \mathrm{~h}$ post-shift, two polypeptides (nos 53 and 121) continued to be synthesized in large amounts; the rates of synthesis of an additional 10 polypeptides, all of which are characteristic of cells grown at $13{ }^{\circ} \mathrm{C}(\operatorname{nos} 29,39,46,47,66,95,109,111,117$ and 137) also increased markedly (Fig. 7e).

\section{Discussion}

From the results of the present study, it appears that the protein synthesis activity at a low temperature is sufficient to permit growth at lower temperatures, and that this is a result of changes in the properties of soluble components involved in protein synthesis. Changes in the membrane transport of amino acids do not appear to be involved. Furthermore, the levels of a small number of proteins in the soluble fraction change after a shift in temperature. It is, therefore, suggested that the difference in the temperature dependence of protein synthesis of cells grown at different temperatures may be related to the changes in the levels of this small number of proteins. Considering that the number of proteins detected by silver-staining of two-dimensional gels is probably less than $10 \%$ of the total number of proteins in the cell, the possibility should not be overlooked that the proteins, which play a regulatory role in the response to a temperature shift, might exist as minor proteins undetectable by silver-staining.

With a shift-up in temperature from $0{ }^{\circ} \mathrm{C}$ to $13^{\circ} \mathrm{C}$, the rate of total protein synthesis increased gradually to a new steady-state level, which was established after a period of a few generations. The rates of synthesis of individual polypeptides changed with time (Fig. 7), exhibiting apparently complex kinetics. At first, the increases in the rates of synthesis of at least 18 polypeptides were very marked (Fig. $7 \mathrm{~b}$ ) and, after $30 \mathrm{~h}$ post-shift, considerable increases in the rates of synthesis of a dozen polypeptides, each characteristic of steadystate growth at $13{ }^{\circ} \mathrm{C}$, were noted (Fig. 7e). These effects on rates of synthesis of certain polypeptides cannot be explained only in terms of general changes in the rate of protein synthesis as it responds passively to temperature, or by the direct effects of restrictions in the uptake of amino acids. In fact, transport of leucine and AIB into cells grown at either $0^{\circ} \mathrm{C}$ or $13{ }^{\circ} \mathrm{C}$ responded to temperature in a similar manner (Table 1 and Fig. 3). Therefore, it is possible that the specific effects seen in the rates of synthesis of some polypeptides are an active regulatory response. 
When cells of a typical mesophilic bacterium, E. coli, are transferred from a low to a high temperature, the rates of synthesis of a small number of proteins, the heatshock proteins, increase transiently (Yamamori et al., 1978; Yamamori \& Yura, 1980, 1982). The hightemperature regulon of $E$. coli consists of 17 genes that are transiently induced, with high rates of expression, by a shift-up in temperature (Neidhardt et al., 1983). These genes are subject to their own individual controls, but their coordinated response to temperature is regulated by an alternative sigma factor of RNA polymerase $\left(\sigma^{32}\right)$, the product of the rpoH (htpR) gene (Grossman et al., 1984; Taylor et al., 1984; Yura et al., 1984). Such induction of heat-shock proteins seems to represent, in part, a homeostatic response at the cellular level to environmental changes in both eukaryotes and prokaryotes. Moreover, such a response system may well be conserved in psychrotrophs and psychrophiles.

In the psychrophilic bacterium Aquaspirillum sp. Res10 , the synthesis of at least 10 proteins (detected by onedimensional gel electrophoresis) is induced by a shift-up in temperature from $0^{\circ} \mathrm{C}$ to either $15^{\circ} \mathrm{C}$ or $20^{\circ} \mathrm{C}$, with maximal induction after $4 \mathrm{~h}$. Furthermore, induction of these proteins seems to be regulated at the transcriptional level (McCallum et al., 1986).

In contrast to the response to heat shock, little is known about the effects of a shift-down in temperature on protein synthesis. In E. coli, about two dozen proteins are preferentially synthesized after a down-shift, in spite of the reduction in the rate of synthesis of most cellular proteins. Among these proteins, seven have been identified; some are involved in transcription and translation (Jones et al., 1987).

In the psychrophilic bacterium Vibrio sp. strain ANT300 , changes in the rates of synthesis of individual polypeptides may also be associated with an active regulatory response at the transcriptional and/or translational level. With respect to the nature of signals responsible for an active response, a variety of evidence (Gallant et al., 1977; Lee et al., 1983a, b; Little et al., 1983; Little \& Bremer, 1984; Pingoud et al., 1983; Reynolds et al., 1983; Ryals et al., 1982a, $b$; Williams et al., 1983) suggests that adenylylated nucleotides, such as ppGpp and AppppA which accumulate as a result of amino acid restriction, nutritional shift, temperature shift and oxidative stress, might be involved in the preferential synthesis and/or regulation of RNA.

In cells of Vibrio sp. strain ANT-300, a shift-up in temperature caused an increased accumulation of ppGpp within a maximum at $4 \mathrm{~h}$ and a simultaneous decrease in the synthesis of RNA. By contrast, a shiftdown in temperature caused an immediate decrease in RNA synthesis and a concurrent decrease in levels of ppGpp (unpublished data).
In $E$. coli, cells exposed to any one of various stresses exhibit different patterns with respect to the accumulation of adenylylated nucleotides (VanBogelen et al., 1987). Moreover, VanBogelen \& Neidhardt (1990) have shown that ppGpp is neither sufficient nor necessary for signal induction of the heat-shock response. Thus, the exact mechanisms by which mediators exert their regulatory effects are still unknown in most cases.

Finally, the results presented here suggest that the adaptation in the rates of synthesis of certain proteins in the psychrophilic bacterium Vibrio sp. ANT-300 enable it to grow efficiently at $13{ }^{\circ} \mathrm{C}$ and $0{ }^{\circ} \mathrm{C}$. The levels of a small number of proteins only have to be adjusted with the change in temperature. Such a temperature-induced control of protein synthesis may be related to a general adaptive response of both eukaryotes and prokaryotes to shifts in temperature in the natural environment.

\section{References}

Broeze, R. J., Solomon, C. J. \& Pope, D. H. (1978). Effects of low temperature on in vivo and in vitro protein synthesis in Escherichia coli and Pseudomonas fluorescens. Journal of Bacteriology 134, 861-874.

Cowing, D. W., Bardwell, J. C. A., Craig, E. A., Woolford, C., Hendrix, R. W. \& Gross, C. A. (1985). Consensus sequence for Escherichia coli heat shock gene promoters. Proceedings of the National Academy of Sciences of the United States of America 82, 2679-2683.

Das, H. K. \& Goldstein, A. (1968). Limited capacity for protein synthesis at zero degrees centigrade in Escherichia coli. Journal of Bacteriology 31, 209-226.

Gallant, J., Palmer, L. \& Pao, C. C. (1977). Anomalous synthesis of ppGpp in growing cells. Cell 11, 181-185.

GeEsey, G. G. \& Morita, R. Y. (1975). Some physiological effects of near-maximum growth temperatures on an obligately psychrophilic marine bacterium. Canadian Journal of Microbiology 21, 811-818.

Goldstein, J., Pollitt, N. S. \& INOUYe, M. (1990). Major cold shock protein of Escherichia coli. Proceedings of National Academy of Sciences of the United States of America 87, 283-287.

Grossman, A. D., Erickson, J. W. \& Gross, C. A. (1984). The htpR gene product of $E$. coli is a sigma factor for heat-shock promoters. Cell 38, 383-390.

Herendeen, S. L., VanBogelen, R. A. \& Neidhardt, F. C. (1979). Levels of major proteins of Escherichia coli during growth at different temperatures. Journal of Bacteriology 139, 185-194.

InNISS, W. E. \& INGRAHAM, J. L. (1978). Microbial life at low temperatures: mechanisms and molecular aspects. In Microbial Life in Extreme Environments, pp. 73-104. Edited by D. J. Kushner. New York: Academic Press.

Jones, P. G., VanBogelen, R. A. \& Neidhardt, F. C. (1987). Induction of proteins in response to low temperature in Escherichia coli. Journal of Bacteriology 169, 2092-2095.

LeE, P. C., Bochner, B. R. \& Ames, B. N. (1983a). AppppA, heatshock stress, and cell oxidation. Proceedings of the National Academy of Sciences of the United States of America 80, 7496-7500.

LEE, P. C., Bochner, B. R. \& AMES, B. N. (1983b). Diadenosine 5',5"$\mathbf{P}^{1}, \mathbf{P}^{4}$-tetraphosphate and related adenylylated nucleotides in $\mathrm{Sal}$ monella typhimurium. Journal of Biological Chemistry 258, 6827-6834.

Lemaux, P. G., Herendeen, S. L., Bloch, P. L. \& Neidhardt, F. C. (1978). Transient rates of synthesis of individual polypeptides in $E$. coli following temperature shifts. Cell 13, 427-434.

LitTle, R. \& BREMER, H. (1984). Transcription of ribosomal component genes and lac in a relA $A^{+}$relA pair of Escherichia coli strains. Journal of Bacteriology 159, 863-869. 
Little, R., Ryals, J. \& Bremer, H. (1983). rpoB mutation in Escherichia coli alters control of ribosome synthesis by guanosine tetraphosphate. Journal of Bacteriology 154, 787-792.

McCallum, K. L., HeikKILA, J. J. \& InNISS, W. E. (1986). Temperature-dependent pattern of heat shock protein synthesis in psychrophilic and psychrotrophic microorganisms. Canadian Journal of Microbiology 32, 516-521.

MOHR, P. W. \& KRAWIEC, S. (1980). Temperature characteristics and Arrhenius plots for nominal psychrophiles, mesophiles and thermophiles. Journal of General Microbiology 121, 311-317.

Neidhardt, F. C. \& VanBogelen, R. A. (1981). Positive regulatory gene for temperature-controlled proteins in Escherichia coli. Biochemical and Biophysical Research Communications 100, 894-900.

Neidhardt, F. C., VanBogelen, R. A. \& LaU, E. T. (1983). Molecular cloning and expression of a gene that controls the high temperature regulon of Escherichia coli. Journal of Bacteriology 153, 579-603.

NiRENBERG, M. W. (1963). Cell-free protein synthesis directed by messenger RNA. Methods in Enzymology 6, 17-23.

O'Farrell, P. H. (1975). High resolution two-dimensional electrophoresis of proteins. Journal of Biological Chemistry 250, 4007-4021.

PatTERson, D. \& Gillespie, D. (1972). Effects of elevated temperatures on protein synthesis in Escherichia coli. Journal of Bacteriology 112, 1177-1183.

Pingoud, A., Gast, G., Block, W. \& Peters, F. (1983). The elongation factor Tu from Escherichia coli, aminoacyl-tRNA, and guanosine tetraphosphate from a ternary complex which is bound by programmed ribosomes. Journal of Biological Chemistry 258, 14200 14205.

Ratkowsky, D. A., Olley, J., McMeekin, T. A. \& Ball, A. (1982). Relationship between temperature and growth rate of bacterial cultures. Journal of Bacteriology 149, 1-5.

Ratkowsky, D. A., Lowry, R. K., McMeekin, T. A., Stokes, A. N. \& ChANDLER, R. E. (1983). Model for bacterial culture growth rate throughout the entire biokinetic temperature range. Journal of Bacteriology 154, 1222-1226.

ReICHARDT, W. \& MORITA, R. Y. (1982). Temperature characteristics of psychrotrophic and psychrophilic bacteria. Journal of General Microbiology 128, 565-568.

Reynolds, S. H., Brantly, C. H., Harris, J. S. \& Chaney, S. G.
(1983). Guanosine 5'-diphosphate 3'-diphosphate levels, carbon source, and ribonucleic acid synthesis in a mutant strain of Escherichia coli. Biocnemistry 22, 1123-1128.

Ryals, J., Little, R. \& BREmer, H. (1982a). Control of rRNA and tRNA syntheses in Escherichia coli by guanosine tetraphosphate. Journal of Bacteriology 151, 1261-1268.

RYALS, J., LitTLE, R. \& BREMER, H. (1982b). Control of RNA synthesis in Escherichia coli after a shift to higher temperature. Journal of Bacteriology 151, 1425-1432.

Taylor, W. E., Straus, D. B., Grossman, A. D., Burton, Z. F., Gross, C. A. \& BURGESs, R. R. (1984). Transcription from a heatinducible promoter causes heat shock regulation of sigma subunit of E. coli RNA polymerase. Cell 38, 371-381.

VANBogelen, R. A. \& NeidhaRdT, F. C. (1990). Ribosomes as sensors of heat and cold shock in Escherichia coli. Proceedings of the National Academy of Sciences of the United States of America 87, 5589-5593.

VanBogelen, R. A., Kelley, P. M., \& Neidhardt, F. C. (1987). Differential induction of heat shock, SOS, and oxidation stress regulons and accumulation of nucleotides in Escherichia coli. Journal of Bacteriology 169, 26-32.

Williams, D. E., Jackson, J. M., III \& Chaney, S. G. (1983). Characterization of RNA synthesis in an Escherichia coli mutant with a temperature-sensitive lesion in stable RNA synthesis. Journal of Bacteriology 153, 616-626.

YAMAMORI, T. \& YURA, T. (1980). Temperature-induced synthesis of specific proteins in Escherichia coli: evidence for transcriptional control. Journal of Bacteriology 142, 843-851.

YAMAMORI, T. \& YURA, T. (1982). Genetic control of heat-shock protein synthesis and its bearing on growth and thermal resistance in Escherichia coli $K-12$. Proceedings of the National Academy of Sciences of the United States of America 79, 860-864.

Yamamori, T., Ito, K. Nakamura, Y. \& Yura, T. (1978). Transient regulation of protein synthesis in Escherichia coli upon shift-up of growth temperature. Journal of Bacteriology 134, 1133-1140

YURA, T., TOBE, T., ITO, K.\& OSAWA, T. (1984). Heat-shock regulatory gene (htpR) of Escherichia coli is required for growth at high temperature but is dispensable at low temperature. Proceedings of the National Academy of Sciences of the United States of America 81, 6803-6807. 